\title{
Prospective Teachers' Cognitive Constructs Concerning Ideal Teacher Qualifications: A Phenomenological Analysis Based on Repertory Grid Technique
}

\section{İshak Kozikoğlu}

Asst. Prof., Yüzüncü Yıl University, Faculty of Education, Department of Educational Sciences Division of Curriculum and Instruction, Turkey, ishakkozikoglu@hotmail.com

The aim of this study is to identify cognitive constructs of prospective teachers about ideal teacher qualifications. This study was designed as phenomenological pattern which is one of the qualitative research designs. The study was conducted with 36 prospective teachers selected from Yüzüncü Y1l University, Faculty of Education. The study group was determined by using criterion sampling method as one of the purposive sampling methods. As a structured interview technique, 'repertory grid' was used for data collection. As a result of the study, 356 cognitive constructs were produced by prospective teachers about teacher qualifications and these cognitive constructs were grouped under ten categories namely communication skills, student centeredness, innovativeness, sensitivity, humaneness/joviality, teaching pedagogical skills, leadership/guidance, professional content knowledge, personal values and professional values by taking functions and similarities into consideration. Dominant categories of prospective teachers' cognitive constructs are teaching pedagogical skills, humaneness/joviality, personal and professional values. Their cognitive constructs play an important role in developing conceptual models of ideal teaching.

Keywords: cognitive constructs, ideal teacher, teacher qualifications, repertory grid, prospective teachers

\section{INTRODUCTION}

Education is one of the most important tools in the development of society and formation of an ideal social order in the movements of changes and innovations within historical process. A development process was initiated through education by making drastic changes in education. The development of a society depends on the presence of qualified human power, qualified human-power is possible with qualified education and qualified education is possible with qualified teachers (Kozikoğlu, 2016).

Education has social, cultural, economic and individual functions. The ability of the education system to fulfill these expected functions depends largely on the quality of the

Citation: Kozikoğlu, İ.. (2017). Prospective Teachers' Cognitive Constructs Concerning Ideal Teacher Qualifications: A Phenomenological Analysis Based on Repertory Grid Technique. International Journal of Instruction, 10(3), 63-78. https://doi.org/10.12973/iji.2017.1035a 
teacher. Current teacher training practices and policies determine the quality of the teacher. Therefore, teachers should be trained with qualified and specific competencies in pre-service teacher education (Senemoğlu, 1990).

The concept of "quality" is defined as ability, competence or effectiveness. In business life, it is defined as the characteristics (knowledge, skills and attitudes) necessary for fulfilling a job (Karadağ, 2011). For centuries, it has been tried to find answers to the questions about who the teacher is, what characteristics he/she should have, how the teacher should be educated, and it is possible to reach thousands of studies both in Turkey and abroad (Senemoğlu, 2001). In order to have highly qualified teachers and teacher training programs, many countries around the world are creating their own teacher standards that are expected to be gained by teachers in pre-service teacher education (Köksal \& Convery, 2013). Just as in the whole world, the qualities and competences that teachers should have in Turkey are constantly being discussed. Teacher training programs are constantly revised according to these qualifications and competences targeted to be gained by teachers (Şişman, 2011).

In Turkey, "General Competencies of Teaching Profession" were determined by the commissions carried out within the "General Directorate of Teacher Training and Education" in 2006. Within this framework; six main competencies, 31 subcompetencies and 233 performance indicators were determined. These main competencies are personal and professional values-professional development, student recognition, teaching and learning process, monitoring and evaluation of learningdevelopment, school-family and community relations, program and content knowledge (MEB, 2008). Teacher competence in teaching and learning is an important factor in determining the success of teaching. The competency of teachers in implementing learning activities has a direct impact on the active participation of learners in learning activities (Copriady, 2014). Actively incorporating learners into the classroom and enabling them to learn effectively requires teachers to have ideal qualifications (Sezer, 2016).

The concept of "ideal" is defined by the Turkish Language Association (2016) as "the one who collects all the superior qualities that the thoughts can design". Similarly, it is defined by Cambridge Advanced Learner's Dictionary (2017) as "perfect, best possible or a way of behaving that is of a very high standard". Ideal characteristics can be determined by the conditions of the present time, the interests, needs and expectations of the individual or the community (Aslan \& Yakar, 2012). Societies pass through a complex, unplanned transformation process that affects our working conditions, our lifestyles and ways of learning. Such a change has a significant impact on schools which are the institutions that are responsible for educating individuals. Today's students have more information resources than even ten years ago thanks to information and communication technologies. This necessitates revision of the functions attached to the school and the teachers (World Bank, 2005). In this case, the ideal qualities that teachers should have must be developed continuously along with the evolving and changing society. 
As teachers work in a variety of ways with various kinds of requirements and standards for quality, they are defined as "ideal" for different reasons (Rusu, Şoitu, \& Panaite, 2012). Educational philosophers proposed various images of the ideal teacher and these images revolved around teachers' basic values and qualifications such as artist in the use of knowledge (Plato), liberator (Freire), role model (Aristotle) etc. (Arnon \& Reichel, 2007). To become an ideal teacher, apart from academic knowledge, a teacher should have emotional and moral values, deep sense of understanding, communication and interaction skills, sense of humor to create a lively classroom environment (Mohapatra, 2006). It can be said that a teacher has various responsibilities and requirements in order to be defined as 'ideal teacher' or 'good teacher'. An ideal teacher should be qualified in terms of personal, social and academic features.

As seen above, there are a number of features related to ideal teacher qualifications. It is important to determine the cognitive constructs of the stakeholders in the education concerning what these qualifications should be. In the literature; there are studies concerning school administrators' cognitive constructs related to teacher qualifications (Sezer, 2016), cognitive constructs of teacher candidates about instructors' qualifications (Aslan \& Akar, 2012), teachers' cognitive constructs of elementary school principals' qualifications (Karadağ, 2011), teachers' cognitive constructs towards school counselors' qualifications (Tanhan, 2013). However, no study has been reached concerning determining cognitive constructs of prospective teachers for ideal teacher qualifications. Teachers are identified as 'ideal' for different reasons and students' perceptions towards ideal teacher qualifications play pivotal role in creating conceptual models of effective teaching (Rusu, Şoitu, \& Panaite, 2012). In this case, it is important to determine cognitive constructs of the prospective teachers regarding ideal teacher qualifications. The aim of this study is to identify cognitive constructs of prospective teachers about ideal teacher qualifications. Their cognitive constructs play an important role in developing conceptual models of ideal teaching.

\section{METHOD}

\section{Research Design}

This research is a qualitative study aimed at identifying cognitive constructs of prospective teachers about ideal teacher qualifications. In this study phenomenological design as one of the qualitative research designs was used. In phenomenological designs, intensive human experiences (Merriam \& Tisdell, 2015) and perceptions of the individuals towards phenomena in which the individual is aware but cannot have an indepth understanding are determined (Yıldırım \& Şimşek, 2011). This design is considered to be proper for the purpose of this study as cognitive constructs of prospective teachers about ideal teacher qualifications are found out through deep analysis.

\section{Study Group}

The study group of this study consists of 36 prospective teachers in Yüzüncü Yıl University, Faculty of Education. In this study, as one of the purposive sampling methods, criterion sampling method was used. In criterion sampling method, the 
criterion is determined for the sample and the units (individual, object, event etc.) meeting the criterion are included in the sample (Büyüköztürk et al, 2012, p. 91). Because of the nature and necessities of the study, the criterion was determined as "to have taken lessons from three teachers with ideal qualifications and three teachers with non-ideal qualifications throughout their education life". In this case, the study group was determined from prospective teachers meeting this criterion. Concerning demographic features of the participants, 14 (\%39) of the prospective teachers are male, $22(\% 61)$ of them are female. Five students were selected from each department that are history, biology, Turkish literature, art, mathematics, social sciences and six students were selected from department of foreign language education. Furthermore, six of the students are first grade, seven of them are second grade, nine of them are third grade and 14 of them are fourth grade students.

\section{Procedure}

The study was conducted in six stages namely, (i) definition of the phenomenon (ii) preparing data collection tool (iii) data collection, (iv) data analysis, (v) providing validity and reliability of the study, and (vi) interpretation of the findings (Karadağ, 2011). These stages are explained in detail below:

(i) Definition of the phenomenon: In this stage, the phenomenon was defined and conceptual tools were created in order to compare and classify ideal teachers' qualifications.

(ii) Preparing the data collection tool: In this study, data were collected with "repertory grid technique" developed by Kelly (2003). This technique is based on structured interview technique in which insight is gained through the ways that the individual distinguishes between different elements by comparing them in group of three (Karapanos \& Martens, 2008) and is a research tool that reveals individuals' underlying constructs that they use in order to interpret the events (Rogers \& Ryals, 2007). The repertory grid form used in this study is shown below in Table 1:

Table 1

$\underline{\text { Repertory Grid Form Sample Used in This Study }}$

Ideal $\frac{\text { Cognitive Constructs }}{\text { - Imagine that the two teachers in each trio exhibit same qualification in a similar manner but third is }}$
different.
- Write your answer as two words, two parts of sentence or two identifications which separated by dashes
(:). Write your ideal qualifications under the pole (X), and the non-ideal qualifications under the pole (O).


(iii) Data collection: Data were collected by the researcher one by one. Each interview lasted about 25 minutes and conducted in four stages. In the first stage, the researcher asked the prospective teachers to think about three teachers having ideal teacher qualifications and three teachers having non-ideal teacher qualifications in their educational life. In the second stage, they were asked to place ideal and non-ideal teachers with their names or nicknames in the target sections of repertory grid form. In the third stage, they were asked to write ideal qualifications of the two teachers who are marked in three teachers and distinguishing them from the third teacher. In that case, 10 two-dimensional cognitive constructs were obtained from each participant. In the fourth stage, they were asked to score the cognitive constructs among 1-5 points in terms of the degree to which the teacher has target qualification. A sample repertory grid form filled by a prospective teacher is shown below in Table 2 :

Table 2

A Sample Repertory Grid Form Filled by A Prospective Teacher

\begin{tabular}{|c|c|c|c|c|c|c|c|}
\hline \multicolumn{6}{|c|}{ Teacher } & \multirow{3}{*}{\multicolumn{2}{|c|}{ Cognitive Constructs }} \\
\hline & Ideal & & & n-Idea & & & \\
\hline \multirow{2}{*}{ 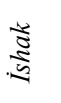 } & \multirow{2}{*}{ 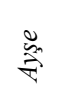 } & \multirow{2}{*}{$\underset{\Xi}{\Xi}$} & \multirow{2}{*}{ 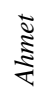 } & \multirow{2}{*}{$\frac{\Sigma}{\stackrel{\Sigma}{\Xi}}$} & \multirow{2}{*}{$\underset{\overrightarrow{\mid}}{\stackrel{\vec{x}}{ }}$} & & \\
\hline & & & & & & (X) Ideal Qualifications & (O) Non-Ideal Qualifications \\
\hline $4 \Delta$ & $4 \Delta$ & 4 & 3 & $1 \Delta$ & 2 & Fair & : Not Fair \\
\hline 5 & $5 \Delta$ & 4 & $3 \Delta$ & 3 & $2 \Delta$ & Knowledgeable & : Not knowledgeable \\
\hline $5 \Delta$ & $4 \Delta$ & 5 & 2 & $1 \Delta$ & 3 & Good communication & : Bad communication \\
\hline
\end{tabular}

(iv) Data analysis: In data analysis, descriptive analysis technique was used. Descriptive analysis consists of four stages forming a thematic framework and characterizing constructs, processing the data according to thematic framework, identification and interpretation of findings (Yıldırım \& Şimşek, 2011, p.224). In this research, these stages were followed. Firstly, in order to form a thematic framework, cognitive constructs developed by prospective teachers were characterized in terms of similarities and common characteristics. Secondly, these cognitive constructs were grouped under categories based on common qualifications, then themes were created that can explain and group the data under certain categories. Thirdly, ideal cognitive constructs were identified under certain categories so that no construct was left out of analysis. Lastly, data were analyzed statistically. The scores of each cognitive construct given by prospective teachers were multiplied according to importance level. In order to determine importance level, the assumption of Gordon (1968) that is "the first produced cognitive constructs are ahead of those obtained later" was taken into consideration (Cited in Karadağ, 2011). So, the score of first produced cognitive construct was multiplied by 10 , the score of last cognitive construct was multiplied by 1 and then a total score for each cognitive construct was obtained.

(v) Providing validity and reliability of the study: In this study, the consistency between coding made by two coders was checked to ensure reliability suggested by Miles and Huberman (1994). So, in order to ensure internal reliability (consistency), expert opinion was used to determine whether the cognitive constructs that are grouped under certain categories represent the target category, then number of agreements and 
disagreements were calculated by using the formula (reliability=number of agreements/total number of agreements + disagreements) suggested by Miles and Huberman (1994). As a result, it was concluded that intercoder correspondence between two coders was found $96 \%$. This is quite acceptable because interceder agreement is expected to be in $90 \%$ range (Miles \& Huberman, 1994, p.64). To ensure internal validity (credibility), the integrity and consistency of the findings were constantly reviewed by the researcher and the findings were supported by direct citations. In order to ensure external validity (transferability), all processes related to data collection tool, data collection and data analysis were described in detail so as to enable comparison for other researchers who will work on the same topic.

(vi) Interpretation of the findings: In the interpretation of the findings, cognitive constructs were grouped under categories and frequencies were determined. Then, cognitive constructs were identified in terms of similar qualifications under categories and organized in a way that will interpret the relationships of themes or the concepts with each other.

\section{FINDINGS}

Data analysis results explain that 356 cognitive constructs were produced by prospective teachers about teacher qualifications. These cognitive constructs were analyzed and grouped under ten categories by taking functions and similarities into consideration. These cognitive construct categories and dominant cognitive constructs under each category are summarized below:

- Communication skills: This category consists of 39 cognitive constructs. According to importance level, three dominant cognitive constructs concerning 'communication skills' are namely; 1) effective communication $[17,190]^{1}$, 2) openness to communication [10, 190], 3) effective speech [4, 190].

- Student centeredness: This category consists of 32 cognitive constructs. According to importance level, three dominant cognitive constructs concerning 'student centeredness' are namely; 1) being interested towards students [13, 190], 2) dealing with students individually [1, 170], 3) dealing with students' problems [21, 162].

- Innovativeness: This category consists of 7 cognitive constructs. According to importance level, three dominant cognitive constructs concerning 'innovativeness' are namely; 1) openness to innovations [36, 190], 2) self-improvement [14, 180], 3) innovator [14, 105].

- Sensitivity: This category consists of 17 cognitive constructs. According to importance level, three dominant cognitive constructs concerning 'sensitivity' are namely; 1) understanding/considerate [15, 190], 2) understanding/considerate [12, 160], 3) considerate [3, 166].

\footnotetext{
${ }^{1}$ The first number in the parentheses refers to code number of the prospective teacher; the second number in the parentheses refers to importance level of the cognitive construct.
} 
- Humaneness/Joviality: This category consists of 58 cognitive constructs. According to importance level, three dominant cognitive constructs concerning 'humaneness/joviality' are namely; 1) good-humored [12, 190], 2) good-humored [11, 180], 3) good-humored [16, 180].

- Teaching pedagogical skills: This category consists of 75 cognitive constructs. According to importance level, three dominant cognitive constructs concerning 'teaching pedagogical skills' are namely; 1) being able to transfer knowledge [6, 220], 2) being able to enrich the subject [7, 190], 3) planning [26, 190].

- Leadership/Guidance: This category consists of 20 cognitive constructs. According to importance level, three dominant cognitive constructs concerning 'leadership/guidance' are namely; 1) guide [18, 200], 2) guide [5, 190], 3) model [3, 180].

- Professional content knowledge: This category consists of 28 cognitive constructs. According to importance level, three dominant cognitive constructs concerning 'professional content knowledge' are namely; 1) knowledgeable [21, 200], 2) content knowledge [8, 190], 3) knowledgeable in the field [32, 184].

- Personal values: This category consists of 41 cognitive constructs. According to importance level, three dominant cognitive constructs concerning 'personal values' are namely; 1) self-reliant [25, 180], 2) self-controlled [17, 180], 3) self-controlled [18, 168].

- Professional values: This category consists of 39 cognitive constructs. According to importance level, three dominant cognitive constructs concerning 'professional values' are namely; 1) fair [35, 170], 2) idealist [32, 168], 3) having responsibility [21, 153].

The importance level of cognitive constructs was calculated by multiplying the scores of each cognitive construct given by prospective teachers with descending numbers, respectively "from 10 to 1 ". Then, the scores of cognitive constructs in each category were summed up one by one. The results concerning importance level of cognitive construct categories are presented in Table 3: 
Table 3

Distribution of Cognitive Construct Categories In Terms Of Importance Level

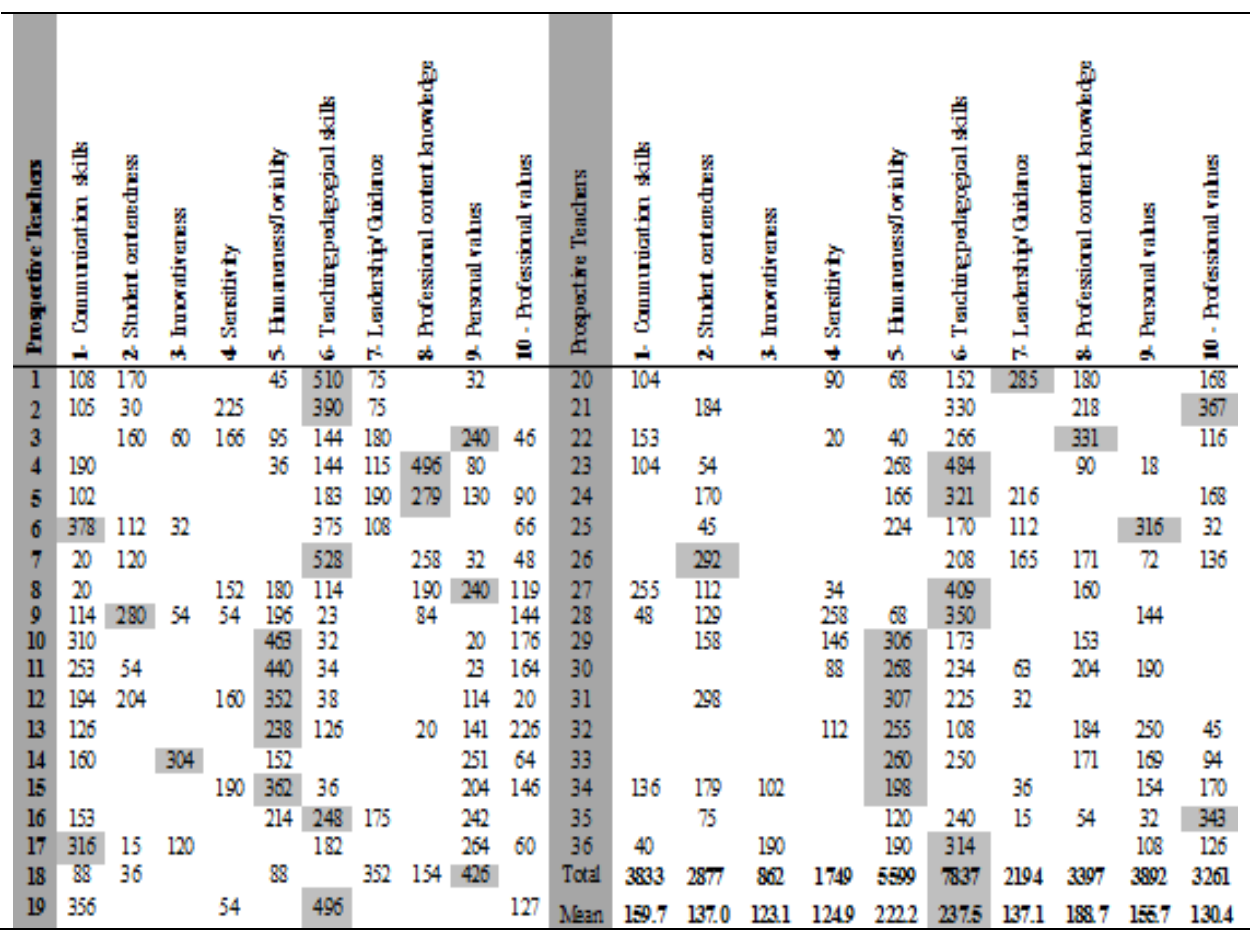

In Table 3, the obtained scores were analyzed in two different ways. Firstly, the scores of each prospective teacher's cognitive construct categories were analyzed and shown on each line. Secondly, cognitive construct categories were shown in grey on each line as the main cognitive construct category for each prospective teacher. Considering the cognitive construct categories' importance level, the first three cognitive construct categories are; (1) humaneness/joviality $[\eta=11, \% 30,5]$, (2) teaching pedagogical skills $[\eta=10, \% 27,7]$, and (3) personal values $[\eta=4, \% 11,1]$, respectively.

In the last two lines of the Table 3, total and mean scores for each cognitive construct category were analyzed and these scores represent the importance level of each cognitive construct category. According to total scores of cognitive construct categories, the first three cognitive construct categories are; (1) teaching pedagogical skills [total=7837], (2) humaneness/joviality [total=5599], and (3) personal values [total=3892], respectively. On the other hand, considering mean scores of cognitive construct categories, the first three cognitive construct categories are; (1) teaching pedagogical skills $[X=237,5],(2)$ humaneness/joviality $[X=222,2]$, and (3) professional content knowledge $[X=188,7]$, respectively. Furthermore, the frequencies and percentages of participants in each cognitive construct category are presented in Table 4: 
Table 4

The Number of Participants in Each Cognitive Construct Categories

\begin{tabular}{|c|c|c|c|}
\hline $\begin{array}{l}\text { Cognitive Construct } \\
\text { Categories }\end{array}$ & $\eta$ & $\%$ & Chart \\
\hline $\begin{array}{l}\text { 1- Communication skills } \\
\text { 2- Student centeredness } \\
\text { 3- Innovativeness } \\
\text { 4- Sensitivity } \\
\text { 5- Humaneness/Joviality } \\
\text { 6- Teaching pedagogical skills } \\
\text { 7- Leadership/Guidance } \\
\text { 8- Professional content } \\
\text { knowledge } \\
\text { 9- Personal values } \\
\text { 10- Professional values }\end{array}$ & $\begin{array}{r}24 \\
21 \\
7 \\
14 \\
27 \\
33 \\
16 \\
\\
18 \\
25 \\
25\end{array}$ & $\begin{array}{r}11.4 \\
10.0 \\
3.3 \\
6.6 \\
12.9 \\
15.7 \\
7.6 \\
\\
8.6 \\
11.9 \\
11.9\end{array}$ & \begin{tabular}{r|r}
35 & \\
30 & \\
25 & \\
20 & \\
15 & \\
10 & \\
5 & \\
0 &
\end{tabular} \\
\hline
\end{tabular}

According to Table 4, concerning the number of participants in each cognitive construct category, the first four construct categories are; teaching pedagogical skills $[\eta=33$, $\% 15,7]$, humaneness/joviality $[\eta=27, \% 12,9]$, and personal- professional values $[\eta=25$, $\% 11,9]$, respectively. On the other hand, the last three cognitive construct categories are; innovativeness $[\eta=7, \% 3,3]$, sensitivity $[\eta=14, \% 6,6]$, and leadership/guidance $[\eta=16$, $\% 7,6]$, respectively

\section{CONCLUSION, DISCUSSION and SUGGESTIONS}

Teachers have a crucial role in educational process. Throughout school life, a student meets a variety of teachers. Each student will have his/her "ideal" type of teacher and has preferences for ideal teacher qualifications (Rusu, Şoitu, \& Panaite, 2012). In this study, it was aimed to identify cognitive constructs of prospective teachers about ideal teacher qualifications. In accordance with this purpose, the study was conducted with 36 prospective teachers by using repertory grid technique. As a result, 356 cognitive constructs were produced by prospective teachers about ideal teacher qualifications and these cognitive constructs were grouped under ten categories namely communication skills, student centeredness, innovativeness, sensitivity, humaneness/joviality, teaching pedagogical skills, leadership/guidance, professional content knowledge, personal values and professional values. Concerning these categories, it can be said that prospective teachers create various qualifications about ideal teacher. These qualifications show consistency with "General Competencies of Teaching Profession" in Turkey that are personal and professional values-professional development, student recognition, teaching and learning process, monitoring and evaluation of learningdevelopment, school-family and community relations, program and content knowledge. Apart from these competencies, it is seen that prospective teachers give importance to effective teacher-student interaction such as communication skills, student centeredness, 
sensitivity, humaneness/joviality in terms of ideal teacher qualifications. This multidimensionality can be explained by the fact that the individual's cognitive constructs are shaped through the addition of new information from the external environment to the existing knowledge and therefore changing the individual's existing knowledge, behaviors and cognitive schemas (Glass \& Holyoak, 1986; Kelly, 2003). Furthermore, it is stated that cognitive constructs are closely related to individual experiences (Karadağ, 2011). As the students are at different grade levels, they differ in educational experiences and types of teachers they met during their educational life, it can be said that prospective teachers' cognitive constructs are influenced by their individual experiences and their learning/knowledge resulting from their interaction with the external environment.

In this study, it is seen that some cognitive constructs are repeated frequently and these constructs can be ordered as good or effective communication, valuing students, understanding/considerate, good-humored, teaching the lesson effectively or well, classroom management, being guide, knowledgeable, patient, reliable, fair, having responsibility etc. In general, these qualifications require deep sense of understanding and effective teacher-student interaction. The importance of a healthy interpersonal teacher-student interaction, deep sense of understanding and humor are emphasized in many studies in the literature (Arnon \& Richel, 2007; Blishen, 1969; Çetin, 2001; Doyran, 2000; Kubovi, 1992; Rogers, 2006; Rusu, Şoitu, \& Panaite, 2012; Taşkafa, 1989; Telli, Brok, \& Çakıroğlu, 2008; YÖK, 1998). Therefore, it can be concluded that students produce ideal teacher characteristics as forming a friendly and lively environment, establishing good relationships with students, having deep sense of understanding as well as professional and content knowledge.

In this study, cognitive constructs produced by prospective teachers and their scores in terms of importance level were analyzed in different ways. As a result of these analyses, it is seen that parallel results were found. Considering the cognitive construct categories' importance level, it was concluded that the first three cognitive construct categories are humaneness/joviality, teaching pedagogical skills and personal values, respectively. Similarly, considering total scores of cognitive construct categories, it was found that the first three cognitive construct categories are teaching pedagogical skills, humaneness/joviality and personal values, respectively. On the other hand, considering mean scores of cognitive construct categories, it was found that the first three cognitive construct categories are teaching pedagogical skills, humaneness/joviality and professional content knowledge, respectively. Concerning the number of participants in each cognitive construct category, it was found that the first four construct categories are teaching pedagogical skills, humaneness/joviality and personal- professional values, respectively. On the other hand, it was concluded that the last three cognitive construct categories are innovativeness, sensitivity and leadership/guidance, respectively. In accordance with the results of these analyses, it can be concluded that ideal teachers should have qualifications such as humaneness, joviality and personal values as well as professional knowledge (content knowledge and pedagogical skills). These results are consistent with the results of previous studies in the literature. 
Most of the research results concerning characteristics of good teacher emphasized two important features of ideal teacher that are professional knowledge (content knowledge and pedagogical skills) and suitable personality (Arnon \& Reichel, 2007). In the study conducted by Musgrove and Taylor (1972), it was found that pupils' expectations from ideal teachers were appropriate personality, classroom management, using effective teaching methods, proper behaviors in the class and organization skills. Similarly, in the study conducted by Blishen (1969), it was found that students desire teachers to be understanding, patient, interested, polite, forming good communication with students, valuing students etc. In the study conducted by Rusu, Şoitu and Panaite (2012), it was found that university students prioritize relational competencies of an ideal teacher and a good student-teacher communication. Kubovi (1992) found that students want teachers to have features such as caring for individual differences, dealing with students, caring for students and being respectful. Furthermore, in the study conducted by Sezer (2016), it was found that school administrators give more priority to the personal characteristics and professional competency of the ideal teachers. Concerning the results of these studies above and the results in this study, it can be concluded that teacher's personality, humanistic approach towards students, professional knowledge and skills are key elements in being perceived as ideal teacher by the students.

Concerning students' images of ideal teacher qualities, teachers' personalities, professional knowledge and their empathic and humane attitude towards their students are critical elements (Arnon \& Reichel, 2007; Lai, 2005). Teacher's personality such as good-humor, empathy, understanding etc. and proper organization of the lesson are suggested as two important factors of a good teaching (Willingham, 2009). For an qualified teacher, academic knowledge is not the only requirement. Apart from knowledgeable information, an ideal teacher should have emotional and moral values. That is to say, he/she should have sense of humor, deep sense of understanding, communication skills, effective interaction with the students (Mohapatra, 2006).

It can be concluded that, concerning ideal teacher qualifications, students or prospective teachers give great importance to the personality such as humaneness, joviality and personal values as well as professional knowledge (content knowledge and pedagogical skills). It can be considered that changing paradigms in education, educational philosophies and arguments on contemporary education are influential on these results. Ideal teacher qualifications of prospective teachers may be shaped by the conditions of the present time and expectations of the individual or the community. While teacher was seen as authoritarian and the only source of knowledge in traditional education theories and educational philosophies, the role of teacher in modern education and contemporary educational philosophies is seen as a guide and consultant. In this case, teachers' emphasizing the personal and humanistic characteristics of the ideal teacher or good teacher and giving importance to the ethical and social aspects of the teacher are consistent with modern education and contemporary educational philosophies.

Teaching in contemporary schools requires establishing relationships with various students with different backgrounds, needs, interests and expectations. Then, it is crucial for teachers to have ideal qualifications for an effective learning (Sezer, 2016). In this 
study, prospective teachers' cognitive constructs about ideal teacher qualifications were determined. In accordance with the results of this study, it is suggested that there should be selective courses in teacher training programs in order to develop prospective teachers' personality, personal values and teaching pedagogical skills. In pre-service teacher education; a warm, lively and interactive environment should be created in the classroom so that prospective teachers can develop their sense of understanding, humor and communication skills. Furthermore, repertory grid technique can be suggested for the researchers especially in educational sciences as this technique can provide them to determine cognitive constructs of individuals on distinctive educational issues.

\section{REFERENCES}

Arnon, S., \& Reichel, N. (2007) Who is the ideal teacher? Am I? Similarity and difference in perception of students of education regarding the qualities of a good teacher and of their own qualities as teachers. Teachers and Teaching, 13(5), 441-464.

Aslan, M., \& Akar, A. (2012). Öğretmen adaylarının öğretim elemanı niteliklerine ilişkin bilişsel kurguları: karşılaştırmalı bir inceleme. İlköğretim Online, 11(4), 10361052.

Blishen, E. (1969). The School That I'd Like. London: Harmondsworth, Penguin.

Büyüköztürk, Ş., K1lıç-Çakmak, E., Akgün, Ö.E., Karadeniz, Ş., \& Demirel, F. (2012). Bilimsel Araştırma Yöntemleri (13.baskı). Ankara: Pegem

Cambridge Advanced Learner's Dictionary (2017). Cambridge dictionary. http://dictionary.cambridge.org/dictionary/english/ideal\#translations 03.04.2017

Cetin S. (2001). Ideal öğretmen üzerine bir araştırma. Milli Eğitim Dergisi, 149, 29-37.

Copriady, J. (2014). Teachers competency in the teaching and learning of chemistry practical. Mediterranean Journal of Social Sciences, 5(8), Doi:10.5901/mjss.2014.v5n8p312.

Doyran, F. (2000). The effects of perceived teacher non-verbal behaviors, teacher behaviors and preferred learning styles on English proficiency level (Unpublished doctoral dissertation). Ankara: Middle East Technical University.

Glass, A. L., \& Holyoak, K. J. (1986). Cognition. NY: Random House. Gordon, C. (1968). Self Conceptions: Configuration Of Content. Harlow: Longman.

Karadağ, E. (2011). Okul müdürlerinin niteliklerine ilişkin olarak öğretmenlerin oluşturdukları bilişsel kurgular: Fenomonolojik bir çözümleme. Ĕgitim ve Bilim, 36 (159).

Karapanos, E., \& Martens, J. B. (2008) The quantitative side of the repertory grid technique: Some concerns. In: Proceedings of the workshop now let's do it in practice: user experience evaluation methods in product development, human factors in computing systems, CHI'08. ACM, NY, USA. 
Kelly, G. A. (2003). The Psychology of Personal Constructs. London: Taylor \& Francis.

Kozikoğlu, İ. (2016). Öğretimin ilk yılı: mesleğin ilk yılındaki öğretmenlerin karşılaştıkları güçlükler, hizmet öncesi eğitim yeterlikleri ve mesleğe adanmışlıkları. Yüzüncü Yıl Üniversitesi, Eğitim Bilimleri Enstitüsü, Van.

Köksal, N., \& Convery, A. (2013). Initial teacher education in Turkey and England: Comparing competencies and standards. Journal of Education and Future, 3, 1-20.

Kubovi, D. (1992) Between the Teacher and the Pupil. Hebrew: Jerusalem, Academon.

Lai, K. C. (2005). Qualifications of the teaching force in the Hong Kong special administrative region, China. In R. M. Ingersoll (Ed.), A Comparative Study of Teacher Preparation and Qualifications in Six Nations (pp. 29-40). Philadelphia, PA: CPRE.

MEB. (2008). Öğretmen Yeterlikleri, Öğretmenlik Mesleği Genel ve Özel Alan Yeterlikleri. Ankara: Devlet Kitapları Müdürlüğü.

Merriam, S. B., \& Tisdell, E. J. (2015). Qualitative Research: A Guide to Design and Implementation. John Wiley \& Sons.

Miles, M. B. \& Huberman, A. M. (1994). Qualitative data analysis (2 $2^{\text {nd }}$ edition). Thousand Oaks, CA: Sage Publications.

Mohapatra, B. K. B. (2006). Ideal teacher. Orissa Review. Retrieved October, 1(2012), 68-80.

Musgrove, F. \& Taylor, P. H. (1972). Pupils' expectation of teachers, in: A. Morison \&. D. Mcintyre (Eds) The Social Psychology of Teaching (Portsmouth, NH, Heineman), 171-182.

Rogers, B. (2006). Classroom Behavior. A Practical Guide To Effective Teaching, Behavior Management And Colleague Support. London: Paul Chapman Publishing.

Rogers, B., \& Ryals, L. (2007). Using the repertory grid to access the underlying realities in key account relationships. International Journal of Market Research, 49, 595-612.

Rusu, C., Şoitu, L., \& Panaite, O. (2012). The ideal teacher: Theoretical and investigative approach. Procedia-Social and Behavioral Sciences, 33, 1017-1021.

Senemoğlu, N. (1990). Öğretmen adaylarına 'genel kültür' kazandırma bakımından fenedebiyat ve eğitim fakültelerinin etkililiği. Çăgdaş Ĕ̆itim Dergisi.

Senemoğlu, N. (2001). Öğrenci görüşlerine göre öğretmen yeterlikleri. Türk Milli Ĕ̌itim Örgütü ve Yönetimi Ulusal Sempozyumu.

Sezer, Ş. (2016). Okul yöneticilerinin ideal öğretmen niteliklerine ilişkin bilişsel kurguları: Repertory grid tekniğine dayalı fenomenolojik bir çözümleme. Eğitim ve Bilim, 41(186), 37-51. 
Şişman, M. (2011). Eğitim Bilimine Giriş (8.baskl). Ankara: Pegem A Yayıncılık.

Tanhan, F. (2013). Repertory grid görüşme tekniğine dayalı olarak okul psikolojik danışmanlarının niteliklerinin incelenmesi. Türk Psikolojik Danışma ve Rehberlik Dergisi, 5(40), 186-197.

Taşkafa, G. (1989). As teachers we are evaluating our students constantly: Have you ever thought how our students evaluate us? Çağdaş Ĕ̈itim, 14, 27-30.

Telli, S., Den Brok, P., \& Çakiroglu, J. (2008). Teachers' and students' perceptions of the ideal teacher. Egitim ve Bilim, 33(149), 118.

Türk Dil Kurumu Sözlüğü. (2016). Güncel Türkçe Sözlük, TDK. http://tdkterim.gov.tr/bts/ 18.12.2016

Willingham, D.T. (2009). Why Don't Students Like School? A Cognitive Scientist Answer Questions About How The Mind Works And What It Means For Your Classroom. San Francisco: Jossey-Bass.

World Bank. (2005). Final report: Learning to teach in the knowledge society.

Yıldırım, A., \& Şimşek, H. (2011). Sosyal bilimlerde nitel araştırma yöntemleri (8.baskı). Ankara: Seçkin Yayıncılık.

YÖK (1998). Cooperation of Faculty And School [In Turkish] Ankara: YÖK. 


\section{Turkish Abstract \\ Öğretmen Adaylarının İdeal Öğretmen Niteliklerine İlişkin Bilişsel Yaklaşımları: Grid Tekniğine Dayalı Fenomenolojik Bir Analiz}

$\mathrm{Bu}$ araștırmanın amacı, öğretmen adaylarının ideal öğretmen niteliklerine ilişkin bilișsel yaklaşımlarını tanımlamaktır. Araştırma nitel araştırma desenlerinden fenomenolojik modelle dizayn edilmiştir. Çalışma grubu amaçlı örnekleme yöntemlerinden ölçüt örnekleme yöntemiyle tanımlanmıştır. Araştırma sonuçlarına göre öğretmen adaylarının ideal öğretmen nitelikleriyle ilgili 356 bilişsel yapı bulunmuş, bu yapılar işlevi ve benzerliklerine göre iletişim yetenekleri, öğrenci merkezlilik, yaratıcılık, duyarlılık, insancıllık, pedagojik beceri öğretimi, liderlik, uzmanlık bilgisi, kişisel değerler ve profesyonel değerler gibi kategorilere ayrılmıştır.

Anahtar Kelimeler: bilişsel yapılar, ideal öğretmen, öğretmen nitelikleri, grid yöntemi, öğretmen adayları

\section{French Abstract}

Les constructions Cognitives de Professeurs Éventuels En ce qui concerne Qualifications de Professeur Idéales: une Analyse Phénoménologique Basée sur Technique de Grille de Répertoire

Le but de cette étude est d'identifier les constructions cognitives de professeurs éventuels de qualifications de professeur idéales. Cette étude a été conçue comme le modèle phénoménologique qui est un des designs(conceptions) de recherche qualitatifs. Le groupe d'étude a été déterminé en utilisant le critère échantillonnant la méthode comme une des méthodes d'échantillonnage résolues. En conséquence de l'étude, 356 constructions cognitives ont été produites par des professeurs éventuels de qualifications de professeur et ces constructions cognitives ont été groupées sous dix catégories à savoir les compétences de communication, l'étudiant se sont concentrées, le fait d'être novateur, la sensibilité, l'humanité/jovialité, enseignant des compétences pédagogiques, la direction/conseils, la connaissance contente(de contenu) professionnelle, des valeurs personnelles et des valeurs professionnelles en prenant des fonctions et des ressemblances dans la considération.

Mots Clés: constructions cognitives, professeur idéal, qualifications de professeur, grille de répertoire, professeurs éventuels

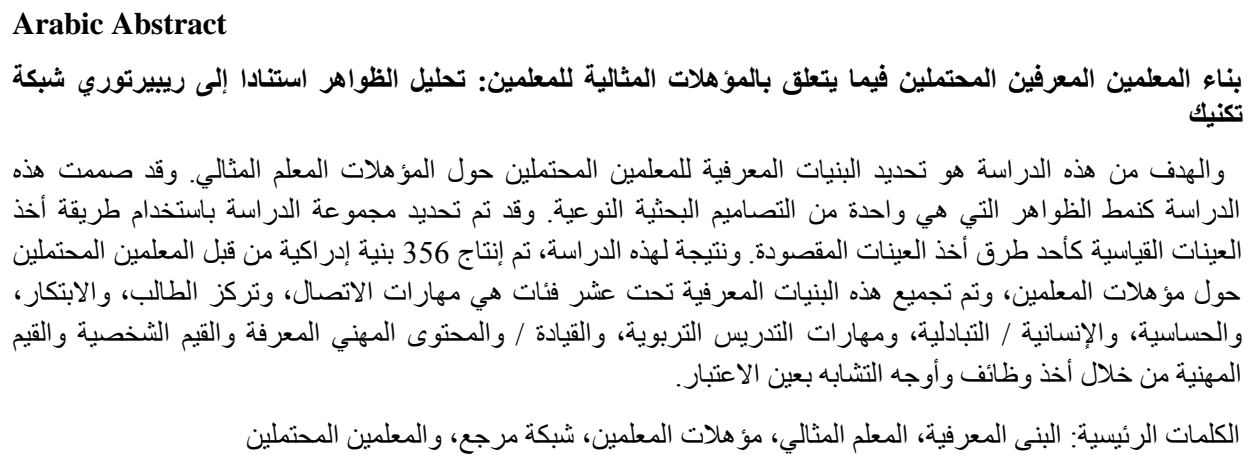




\section{German Abstract \\ Kognitive Konstrukteure der künftigen Lehrkräfte über ideale Lehrerqualifikationen: Eine phänomenologische Analyse basierend auf Repertory Grid Technik}

Das Ziel dieser Studie ist es, kognitive Konstrukte von künftigen Lehrern über ideale Lehrerqualifikationen zu identifizieren. Diese Studie wurde als phänomenologisches Muster entworfen, das eines der qualitativen Forschungsdesigns ist. Die Studiengruppe wurde unter Verwendung der Kriterium-Probenahme-Methode als eine der zweckmäßigen Probenahmeverfahren bestimmt. Als Ergebnis der Studie wurden 356 kognitive Konstrukte von künftigen Lehrern über Lehrerqualifikationen produziert und diese kognitiven Konstrukte wurden unter zehn Kategorien zusammengefasst, nämlich Kommunikationsfähigkeit, studentische Zentriertheit, Innovationsfähigkeit, Sensibilität, Humanität / Jovialität, pädagogische Fähigkeiten, Lehre / Führung, Professionelle Inhalte, persönliche Werte und professionelle Werte durch Berücksichtigung von Funktionen und Gemeinsamkeiten.

Schlüsselwörter: kognitive konstrukte, ideale lehrer, lehrerqualifikationen, repertorium, zukünftige lehrer

Malaysian Abstract

Membina Prospektif Kognitif Guru Mengenai Kelayakan Guru Ideal: Analisis Fenomenologi Berdasarkan Teknik Grid

Tujuan kajian ini adalah untuk mengenal pasti konstruk kognitif bakal guru tentang kelayakan guru ideal. Kajian ini telah direka sebagai corak fenomenologi yang merupakan salah satu reka bentuk penyelidikan kualitatif. Kumpulan kajian telah ditentukan dengan menggunakan kaedah persampelan kriteria sebagai salah satu kaedah persampelan bertujuan. Hasil daripada kajian itu, 356 konstruk kognitif telah dihasilkan oleh bakal guru-guru tentang kelayakan guru dalam membina kognitif dan telah dikumpulkan di bawah sepuluh kategori iaitu kemahiran komunikasi, berpusatkan pelajar, inovasi, menegakkan prinsip kemanusiaan / sifat riang, mengajar pedagogi kemahiran, kepimpinan / bimbingan, pengetahuan kandungan profesional, nilai-nilai peribadi dan nilai-nilai profesional dengan mengambil fungsi dan persamaan kira.

Kata Kunci: membina kognitif, guru ideal, kelayakan guru, grid senarai lagu-lagu, bakal guru

\section{Russian Abstract}

Познавательные Конструкции Перспективных Учителей, Касающиеся Идеальных Квалификаций Учителей: Феноменологический Анализ, Основанный на Технике Репертуарных Сеток

Целью данного исследования является выявление когнитивных конструкций перспективных учителей об идеальных квалификациях преподавателей. Это исследование было разработано как феноменологическая модель, которая является одним из качественных исследовательских проектов. Исследовательская группа была определена с использованием метода выборки критериев как одного из целенаправленных методов выборки. В результате исследования 356 когнитивных конструкций были подготовлены перспективными учителями и эти когнитивные конструкции были сгруппированы по десяти категориям, а именно навыки общения, сосредоточенность студентов, инновационность, чувствительность, человечность,веселость, педагогические навыки, руководство, знание профессионального контента, личные ценности и профессиональные ценности, принималось во внимание функции и сходства.

Ключевые Слова: когнитивные конструкции, идеальный учитель, квалификация учителя, репертуарная сетка, перспективные учителя 